\title{
Growth, Yield, Nutrient Uptake and Quality of Maize (Fodder) as Influenced by Soil Application of Cattle Urine and Nitrogen Levels in Inceptisol
}

\author{
P. S. Janjal ${ }^{1 *}$, A. B. Jadhav ${ }^{1}$, A. V. Patil ${ }^{1}$ and S. T. Pachpute ${ }^{2}$ \\ ${ }^{1}$ Department of Soil Science and Agricultural Chemistry, ${ }^{2}$ Department of Animal Science and \\ Dairy Science, College of Agriculture, Pune, Mahatma Phule Krishi Vidyapeeth, Rahuri, \\ Maharashtra, India \\ *Corresponding author
}

\section{Keywords}

Cattle urine, soil application, quality, nutrient uptake and yield of maize (fodder)

Article Info

Accepted: 20 June 2021 Available Online: 10 July 2021

\section{A B S T R A C T}

The pot culture experiment was conducted to assess the "growth, yield, nutrient uptake and quality of maize (fodder) as influenced by soil application of cattle urine and nitrogen levels in Inceptisol" at the Division of Soil Science and Agricultural Chemistry and Animal Husbandry and Dairy Science, College of Agriculture, Pune, during Kharif-2019. There were seven treatment viz., 1) Absolute control; 2) Recommended dose of fertilizers 100:50:50 kg ha ${ }^{-1} \mathrm{~N}, \mathrm{P}_{2} \mathrm{O}_{5}$ and $\mathrm{K}_{2} \mathrm{O}$; 3) General recommended dose of fertilizers 100:50:50 kg ha ${ }^{-1} \mathrm{~N}, \mathrm{P}_{2} \mathrm{O}_{5}$ and $\mathrm{K}_{2} \mathrm{O}+\mathrm{FYM} @ 5 \mathrm{tha}$ ${ }^{1}$; 4) $25 \% \mathrm{RDN}+75 \% \mathrm{~N}$ through cattle urine + FYM @ $5 \mathrm{t} \mathrm{ha}^{-1}$; 5) $50 \% \mathrm{RDN}+50 \%$ $\mathrm{N}$ through cattle urine+ + FYM @ $5 \mathrm{t} \mathrm{ha}^{-1}$;6) 75\% RDN + 25\% N + FYM @ $5 \mathrm{t} \mathrm{ha}^{-1}$; 7) $100 \% \mathrm{~N}$ through cattle urine + FYM @ $5 \mathrm{t} \mathrm{ha}^{-1}$ and three replications in completely randomized design. Periodical plant height and number of functional leaves at 20,40 and 60 DAS was found to be significantly higher with the soil application 50\% RDN through urea + 50\% N through cattle urine along with FYM @ $5 \mathrm{tha}^{-1}$. The magnitude of increase in the leaf area was found higher from 494 to 969 $\mathrm{cm}^{2}$ at 40 to 60 DAS than 20 to 40 DAS (203 to $494 \mathrm{~cm}^{2}$ ) with the application of $75 \%$ RDN through urea $+25 \% \mathrm{~N}$ through cattle urine + FYM @ $5 \mathrm{t} \mathrm{ha}^{-1}$. Soil application of $75 \%$ RDN through urea $+25 \% \mathrm{~N}$ through cattle urine with FYM @ $5 \mathrm{t} \mathrm{ha}^{-1}$ reported significantly higher chlorophyll in fodder maize. Soil application of $75 \%$ RDN through urea $+25 \% \mathrm{~N}$ through cattle urine + FYM @ $5 \mathrm{t} \mathrm{ha}^{-1}$ reported significantly higher nitrogen, phosphorous, potassium, iron, zinc and copper uptake by fodder maize. Similar treatment also recorded significantly higher green fodder (984 $\left.\operatorname{g~pot}^{-1}\right)$ and dry matter (423.11 $\mathrm{g} \mathrm{pot}^{-1}$ ) yield of maize. Significantly higher crude protein and total sugar was reported with $75 \% \mathrm{RDN}$ through urea $+25 \% \mathrm{~N}$ through cattle urine with FYM @ $5 \mathrm{t} \mathrm{ha}^{-1}$ while higher crude fiber was reported in absolute control rest of the treatment. Application of 100\% N through cattle urine + + FYM @ $5 \mathrm{t} \mathrm{ha}^{-1}$ recorded higher $\mathrm{ADF}$ and $\mathrm{ADF}$ content in maize (fodder). 


\section{Introduction}

The expanded food needs of future must be met through intensive agriculture without much expansion in the arable land. The decline in growth rate of productivity of major crops as well as rate of resources under intensive cropping system have possibly resulted from deterioration in physical, chemical and biological quality of soils. Higher fertilizer cost, increased concern for long term soil productivity and ecological sustainability have stimulated a great deal of research on organic sources as substitute or supplement to chemical fertilizer.

Since the amount of $\mathrm{N}$ or other nutrients that could be added through different organic sources alone is not sufficient to meet all the requirement different crops. Therefore integrated use of fertilizers, different nutrient sources of organic origin with biofertilizers can meet the nutrient demand of present intensive agriculture without causing ill effects on soil ecosystem..Balance fertilization is the key to improve soil physical, chemical and biological properties of soil, low productivity, enhance nutrient use efficiency and rectify and reclaim multi-nutrient deficiencies (Goswami, N. N. (2006)). In India farmer pay good attention for collection and utilization of cattle dung in the form of FYM but very little or no attention has been given in the collection and utilization of cattle urine. Cattle urine contains $95 \%$ water, $2.5 \%$ urea, $2.5 \%$ others (mineral salts, hormones and enzymes. Total $\mathrm{N}$ in the cattle urine ranged

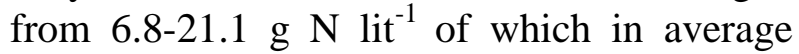
$69 \%$ was urea, $73 \%$ allantoin, $5.8 \%$ uric acid and $0.5 \%$ xanthin plus hypoxanthin, $1.3 \%$ free amino acid nitrogen and $2.8 \%$ on ammonia. This nutrient source is available to farmer free of cost in their own house, being organic in nature it is eco friendly has no adverse effect on ecosystem and human health (Pradhan et al., 2018). Maize has an important place in the food grain basket of our country and is the third most important versatile food grain crop due to its importance in food, feed, corn starch, etc. As per the $X^{\text {th }}$ five year plan Government of India, the demand for green fodder will reach to 1.170 million tones and 650 million tones of dry forage and 150 million tones of concentrate feed in 2025 . Green forage are rich and cheapest source of carbohydrates, proteins, vitamins and minerals for dairy animals. Therefore this study was undertaken to assess the effect of cattle urine through soil application for nitrogen substitution on growth, yield and nutrient uptake by fodder maize in Inceptisol

\section{Materials and Methods}

Pot culture experiment was conducted to study the "growth, yield, nutrient uptake and quality of maize (fodder) as influenced by soil application of cattle urine and nitrogen levels in Inceptisol" at the Division of Soil Science and Agricultural Chemistry and Animal Husbandry and Dairy Science, College of Agriculture, Pune, MPKV during Kharif2019. There were seven treatment viz., 1) Absolute control; 2) Recommended dose of fertilizers 100:50:50 kg ha ${ }^{-1} \mathrm{~N}, \mathrm{P}_{2} \mathrm{O}_{5}$ and $\mathrm{K}_{2} \mathrm{O}$;

3) General recommended dose of fertilizers 100:50:50 kg ha ${ }^{-1} \mathrm{~N}, \mathrm{P}_{2} \mathrm{O}_{5}$ and $\mathrm{K}_{2} \mathrm{O}+\mathrm{FYM} @$ $5 \mathrm{t} \mathrm{ha}^{-1}$; 4) $25 \% \mathrm{RDN}+75 \% \mathrm{~N}$ through cattle urine + + FYM @ $5 \mathrm{t} \mathrm{ha}^{-1}$; 5) 50\% RDN + $50 \% \mathrm{~N}$ through cattle urine+ + FYM @ $5 \mathrm{t} \mathrm{ha}^{-}$ ; 6) $75 \% \mathrm{RDN}+25 \% \mathrm{~N}+\mathrm{FYM} @ 5 \mathrm{t} \mathrm{ha}^{-1}$; 7) $100 \% \mathrm{~N}$ through cattle urine ++ FYM @ $5 \mathrm{t}$ $\mathrm{ha}^{-1}$ and three replications in completely randomized design. Nitrogen substitutions as per treatment were carried out on the basis of nitrogen content (basal dose 0.35 and 30 DAS 0.45 per cent) (table 1$)$. In order to substitute $25,50,75$ and 100 per cent nitrogen, 80 and 65, 160 and 130, 240 and 195, 320 and $260 \mathrm{ml}$ of cattle urine was diluted ten times with tap water at each application and applied to soil as basal dose and 30 DAS. 
The required quantity of surface soil up to depth $15 \mathrm{~cm}$ was collected from the farm survey number 57, plot number 3, Division of Animal Husbandry and Dairy Science, College of Agriculture, Pune. The experimental soil was characterized by black colour dominated by montmorillonite clay with high coefficient of expansion and shrinkage which comes under the Typic Haplustept. The soil was moderately calcareous $\left(\mathrm{CaCO}_{3}: 2.20 \%\right)$ with $\mathrm{pH}: 7.90$, EC: $0.23 \mathrm{~d} \mathrm{Sm}^{-1}$ and organic carbon: $0.52 \%$. The alkaline $\mathrm{KMnO}_{4}-\mathrm{N}$, Olsen's $\mathrm{P}$ and $\mathrm{NH}_{4} \mathrm{OAC}-\mathrm{K}$ in the experimental soil were 35.32 and $558.00 \mathrm{~kg} \mathrm{ha}^{-1}$ respectively. The pots with diameter $41 \mathrm{~cm}$ and height $38 \mathrm{~cm}$ with approximately $30 \mathrm{~kg}$ soil capacity were used for this experiment. The collected soil were processed and allowed to pass through 2 mm sieve. This soil was filled in 21 pots @ 25 $\mathrm{kg}$ soil in each pot.

Treatment wise required quantity of $\mathrm{N}, \mathrm{P}_{2} \mathrm{O}_{5}$, and $\mathrm{K}_{2} \mathrm{O}$ through urea, single super phosphate and murate of potash were mixed thoroughly with soil. The nitrogen @ 50\% N along with $100 \% \mathrm{P}_{2} \mathrm{O}_{5}, 100 \% \mathrm{~K}_{2} \mathrm{O}$ and FYM @ $5 \mathrm{t} \mathrm{ha}^{-}$ ${ }^{1}$ were mixed at the time of sowing as basal dose and remaining $50 \% \mathrm{~N}$ either through urea or cattle urine was applied at 30 DAS of maize.

The soil $\mathrm{KMnO}_{4}-\mathrm{N}$, Olsen's-P and $\mathrm{N}$ $\mathrm{NNH}_{4} \mathrm{OA}-\mathrm{K}$ was analyzed by using methods given by Subbia and Asijia, 1956, Olsen et al., 1954 and Knudsen et al., 1982 respectively. The soil $\mathrm{CaCO}_{3}$ content was assessed by rapid titration method as prescribed by Jackson, 1973. The truthful maize seed of variety African tall was procured from Division of Animal Husbandry and Dairy Science, College of Agriculture Pune. There were total eight seed seeds sown equidistantly and four plants were maintained throughout experiment. Cattle urine was analyzed for nutrient composition before every soil application by following standard method (Table 2). During soil application of cattle urine, due care was taken by considering foliage of maize at respective growth stage. The height of the plant was measured from the base to the top. The number of fully opened functional leaves of four plants from each pot were counted and recorded. The length of fully opened functional leaf was measured from the base of leaf to the tip and width at middle portion for four plants. The leaf area $\left(\mathrm{cm}^{2}\right)$ was calculated by multiplying length of leaf $(\mathrm{cm})$ and width $(\mathrm{cm}) \times 0.75$ correction factor as given by Tanko and Hassan (2016). The four plants from each pot was harvested and immediately weighed in gram pot ${ }^{-1}$. The four maize plants from each pot were cut down at harvest and weighed fresh. The composite samples from each pot were air dried, oven dried and accordingly percent dry matter was calculated. Nitrogen, phosphorous and potassium were analyzed from composite sample of fodder maize. The nutrient concentration was analyzed by digesting composite fodder maize sample. The nutrient uptake was calculated by using dry matter and nutrient concentration and expressed in $\mathrm{g} \mathrm{pot}^{-1}$ for N, P and K. Quality parameters of maize (fodder) were determined by standard methods as states in A.O.A.C 2019. The crude protein content in maize fodder was estimated by analyzing nitrogen content (Micro- Kjeldhal method) in fodder maize and multiplied by a factor 6.25 to get the crude protein content and expressed in percentage.

Crude fibre $(\mathrm{CF})$ in fodder maize at harvest was determined by using Soxhalet apparatus with organic solvents and expressed in percentage. Acid detergent fibre (ADF) and neutral detergent fibre(NDF)content in fodder maize at harvest was determined by fritted glass crucible method on dry matter basis and expressed in percent. Total sugar content was estimated by following anthrone method (Hedge and Hofreiter, 1962). 


\section{Results and Discussion}

\section{Growth}

Soil application of 50\% RDN through urea + $50 \% \mathrm{~N}$ through cattle urine along with FYM @ 5t ha ${ }^{-1}$ recorded significantly higher plant height at $(61,107$ and $149 \mathrm{~cm})$ and number of functional leaves (7, 9 and 11) at 20,40 and 60 DAS of maize respectively (figure 1 to 2 ). This was found to be closely followed by application of $75 \%$ RDN through urea $+25 \%$ $\mathrm{N}$ through cattle urine + FYM @ $5 \mathrm{t} \mathrm{ha}{ }^{-1}$. However the magnitude of increase in maize plant height each growing stage was found higher with the application of 50\% RDN through urea $+50 \% \mathrm{~N}$ through cattle urine+FYM @ $5 \mathrm{t} \mathrm{ha}^{-1}$.

Periodical leaf area of maize was found to be increased consistently in all the treatments of cattle urine and nitrogen application but the magnitude of increase was found to be higher between 40 to 60 DAS than 20 to 40 DAS (figure 3). Application of $75 \%$ RDN through urea $+25 \% \mathrm{~N}$ through cattle urine with FYM @ $5 \mathrm{t} \mathrm{ha}^{-1}$ recorded significantly higher leaf area at 20 DAS $\left(203 \mathrm{~cm}^{2}\right), 40$ DAS $\left(494 \mathrm{~cm}^{2}\right)$ and 60 DAS $\left(969 \mathrm{~cm}^{2}\right)$ which was followed by the application of $50 \% \mathrm{~N}$ through urea $+50 \%$ $\mathrm{N}$ through cattle urine+FYM @ $5 \mathrm{t} \mathrm{ha}^{-1}(162$, 421 and $666 \mathrm{~cm}^{2}$ ) respectively. The magnitude of increase in the leaf area was found higher from 494 to 969 at 40 to 60 DAS than 20 to 40 DAS (203 to 494) with the application of $75 \%$ RDN through urea $+25 \% \mathrm{~N}$ through cattle urine+FYM @ $5 \mathrm{tha}^{-1}$. However the increase in leaf area between 40 to 60 DAS (421 to 666 $\mathrm{cm}^{2}$ ) was higher as compare to 20 to 40 DAS $\left(162\right.$ to $\left.421 \mathrm{~cm}^{2}\right)$ with the application of $50 \%$ $\mathrm{N}$ through urea $+50 \% \mathrm{~N}$ through cattle urine+FYM @ $5 \mathrm{t} \mathrm{ha}^{-1}$.

Cattle urine contains essential nutrients along with auxin and growth hormones which might have accelerated the cell growth and enlargement that might have increased vegetative growth of maize. Sharma et al., 2016 reported highest biological yield of broccoli (sum of curd, shoot and root weights) $36.7 \mathrm{t} / \mathrm{ha}$ with the foliar application of nitrogen @ $150 \mathrm{~kg} / \mathrm{ha}$ through urine. Similar results were also recorded by Iqbal et al., (2014). They reported that application of $75 \%$ RDN along with three foliar sprays @ 10\%, taken at 25, 45 and 65 DAS recorded higher plant height, number of functional leaves and fodder yield of maize.

The results of the study also obtained a corresponding result that increased urine use can increase the components of plant growth such as improving the functions of plants due to presence of auxin in cattle urine. However use of cattle urine enhanced absorption of nutrients thereby maximum growth of vegetative growth of sorghum. Further, high growth of maize caused by cattle urine application with its hormone that stimulated growth of plant and it also contain considerable amount of nitrogen \& potassium (Aisha et al., 2011).

Soil application of $75 \%$ RDN through urea + 25\% N through cattle urine with FYM @ $5 \mathrm{t}$ $\mathrm{ha}^{-1}$ reported significantly higher chlorophyll content $3.24,3.45$ and $3.68 \mathrm{~g}$ fresh weight ${ }^{-1}$ which was followed by the application of 50\% RDN through urea+ $50 \% \mathrm{~N}$ through cattle urine + FYM @ $5 \mathrm{tha}^{-1}(2.97,3.32$ and $3.55 \mathrm{~g}$ fresh weight ${ }^{-1}$ ) at 20,40 and 60 DAS respectively (figure 4). Application of nitrogen either@25,50 and 75\% through cattle urine reported higher synthesis of chlorophyll at 40 and 60 DAS than rest of the treatments. It could be observed from the data that chlorophyll synthesis in cattle urine applied treatments for the substitution of nitrogen was doubled at 20, 40 and 60 DAS of maize (fodder) than absolute control. The increase in chlorophyll in maize (fodder) might be due to magnesium, nitrogen, phosphorous and 
potassium content in cattle urine along with certain growth hormones. Further Panchagavya and cattle urine contains kinetin which might have increase the cytokinins in the leaf as a consequences there was increase in chlorophyll in leaf and developed of photosynthetic activity for large period (Gopakkali and Sharanappa 2013). Tamaraker et al., (2016) also observed similar results with cow urine application @ 5 and 10\% concentration, which significantly improved all vegetative parameter of gladiolus viz. earlier 50\% emergence of corms, plant height, number of leaves, length and width of leaf. Further Chute et al., (2017) also reported similar effect of cow urine @ 4\% and NAA @ 50 ppm recorded higher chlorophyll.

\section{Nutrient uptake}

\section{Macronutrients and micronutrients}

Soil application of $75 \%$ RDN through urea + $25 \% \mathrm{~N}$ through cattle urine + FYM @ $5 \mathrm{t} \mathrm{ha}^{-1}$ reported significantly higher nitrogen $(7.49 \mathrm{~g}$ $\left.\operatorname{pot}^{-1}\right)$, phosphorous (3.68 g pot $^{-1}$ ) and potassium $\left(9.0 \mathrm{~g} \mathrm{pot}^{-1}\right)$ uptake which was followed by $50 \%$ RDN through urea $+50 \% \mathrm{~N}$ through cattle urine + FYM @ $5 \mathrm{t} \mathrm{ha}^{-1}$ (5.85, 2.43 and $7.48 \mathrm{~g} \mathrm{pot}^{-1}$ ) respectively (table 2). However, application of $100 \% \mathrm{~N}$ through cattle urine +FYM @ $5 \mathrm{t} \mathrm{ha}^{-1}$ recorded 6.31, 3.54 and $8.45 \mathrm{~g} \mathrm{pot}^{-1}$ uptake of nitrogen, phosphorous and potassium. Lower uptake of nitrogen $\left(0.79 \mathrm{~g} \mathrm{pot}^{-1}\right)$, phosphorous $(0.26 \mathrm{~g}$ $\left.\operatorname{pot}^{-1}\right)$ and potassium (1.43 $\left.\mathrm{g} \mathrm{pot}^{-1}\right)$ by maize recorded with no application of any nitrogen fertilizer or cattle urine (Absolute control).

Higher uptake of nitrogen, phosphorous and potassium by fodder maize was reported with cattle urine which was rich in nitrogen, phosphorous, potassium, calcium and magnesium that stimulated growth of maize (table 4). Pradhan et al., (2018) reported application of $1200 \mathrm{~L} \mathrm{ha}^{-1}$ cattle urine. Further they concluded that application of cattle urine in soil recorded higher total nitrogen, available phosphorous and exchangeable calcium and magnesium along with improvement in soil texture and structure. Nwite et al., (2015) also concluded improvement in the rate of mineralization which has stimulated growth of maize. Application of urine increased nitrogen concentration in grass and enhanced concentration of potassium in grass and clover (Ledgord et al., 1982). Singh et al., (2014) concluded that application of cattle slurry@ $10 \mathrm{~kg} / 10 \mathrm{~m}^{2}$ plot or $12 \mathrm{~kg} / 10 \mathrm{~m}^{2}$ recorded at par results for yield and uptake of maize (fodder).

Significantly higher iron (1082 $\left.\mathrm{mg} \mathrm{pot}^{-1}\right)$, zinc (150.70 mg pot $\left.{ }^{-1}\right)$ and cooper $\left(17.35 \mathrm{mg} \mathrm{pot}^{-1}\right)$ uptake by maize were reported with the application of $75 \%$ RDN through urea $+25 \%$ $\mathrm{N}$ through cattle urine + FYM @ $5 \mathrm{tha}^{-1}$.

While 100 percent $\mathrm{N}$ application through cattle urine was followed after this for iron uptake by maize (table 4). Higher uptake of micronutrients by maize with cattle urine application might be due to presence of nutrients, enzymes, growth stimulants and hormones which enhanced growth rate and uptake. Auxin present in cattle urine might have played role in root formation by increasing the number and length of roots. Increased urine use can increase the components of plant growth such as improving the functions of plants with higher absorption of nutrients. Similar results were also reported by Pradhan et al., (2018) and Nwite et al., (2015). 
Table.1 Nutrient composition in cattle urine

\begin{tabular}{|c|c|c|c|c|}
\hline Sr. No & Parameter & $\begin{array}{c}\text { Before } \mathbf{1}^{\text {st }} \text { soil } \\
\text { application }\end{array}$ & $\begin{array}{c}\text { Before 2 } \\
\text { application }\end{array}$ & Average \\
\hline $\mathbf{1}$ & $\mathrm{pH}$ & 7.09 & 8.50 & 7.63 \\
\hline $\mathbf{2}$ & $\mathrm{EC}\left(\mathrm{dSm}{ }^{-1}\right)$ & 16.71 & 18.65 & 18.45 \\
\hline $\mathbf{3}$ & $\mathrm{OC}(\%)$ & 1.67 & 1.56 & 1.81 \\
\hline $\mathbf{4}$ & $\mathrm{N}(\%)$ & 0.35 & 0.45 & 0.57 \\
\hline $\mathbf{5}$ & $\mathrm{P}(\%)$ & 0.052 & 0.008 & 0.048 \\
\hline $\mathbf{6}$ & $\mathrm{K}(\%)$ & 0.84 & 0.64 & 0.86 \\
\hline $\mathbf{7}$ & $\mathrm{Ca}(\%)$ & 0.02 & 0.010 & 0.014 \\
\hline $\mathbf{8}$ & $\mathrm{Mg}(\%)$ & 0.042 & 0.054 & 0.044 \\
\hline $\mathbf{9}$ & $\mathrm{SO}(\%)$ & 0.035 & 0.052 & 0.040 \\
\hline $\mathbf{1 0}$ & $\mathrm{Fe}(\mathrm{ppm})$ & 23.00 & 11.00 & 27.67 \\
\hline $\mathbf{1 1}$ & $\mathrm{Mn}(\mathrm{ppm})$ & 0.012 & 0.013 & 0.012 \\
\hline $\mathbf{1 2}$ & $\mathrm{Zn}(\mathrm{ppm})$ & 0.011 & 0.011 & 0.011 \\
\hline $\mathbf{1 3}$ & $\mathrm{Cu}(\mathrm{ppm})$ & 0.012 & 0.013 & 0.012 \\
\hline $\mathbf{1 4}$ & $\mathrm{Colour}$ & Indian yellow & Indian yellow & \\
\hline
\end{tabular}

Table.2 Nutrient uptake by maize (fodder) as influenced by soil application of cattle urine and nitrogen levels in Inceptisol

\begin{tabular}{|c|c|c|c|c|c|c|c|}
\hline \multirow[t]{2}{*}{ Treatments } & \multicolumn{3}{|c|}{$\begin{array}{c}\text { Macronutrient uptake } \\
\left(\mathrm{g} \mathrm{pot}^{-1}\right)\end{array}$} & \multicolumn{4}{|c|}{$\begin{array}{l}\text { Micronutrient uptake } \\
\left(\mathrm{mg} \mathrm{pot}^{-1}\right)\end{array}$} \\
\hline & $\mathbf{N}$ & $\mathbf{P}$ & $\mathbf{K}$ & $\mathbf{F e}$ & Mn & Zn & $\mathbf{C u}$ \\
\hline Absolute control & 0.79 & 0.26 & 1.43 & 79 & 15.12 & 54.72 & 10.84 \\
\hline RDF & 1.63 & 0.56 & 3.42 & 172 & 26.47 & 64.20 & 18.25 \\
\hline GRDF+FYM@5 $\mathrm{t} \mathrm{ha}^{-1}$ & 2.35 & 0.84 & 3.87 & 273 & 41.17 & 66.93 & 10.51 \\
\hline $25 \%$ RDN + $75 \%$ N CU + FYM @ $5 \mathrm{tha}^{-1}$ & 3.23 & 2.13 & 5.21 & 402 & 58.45 & 93.06 & 11.17 \\
\hline $50 \%$ RDN + 50\% N CU + FYM @ $5 \mathrm{tha}^{-1}$ & 5.85 & 2.43 & 7.48 & 592 & 72.98 & 126.93 & 13.97 \\
\hline 75\% RDN+25\% N CU + FYM @ $5 \mathrm{tha}^{-1}$ & 7.49 & 3.68 & 9.00 & 1082 & 90.89 & 150.70 & 17.35 \\
\hline 100\% N CU+FYM@ 5 t ha ${ }^{-1}$ & 6.31 & 3.54 & 8.45 & 1,075 & 61.56 & 129.32 & 13.30 \\
\hline S.E. \pm & 0.35 & 0.06 & 0.29 & 28.31 & 2.85 & 4.90 & 1.27 \\
\hline CD at $5 \%$ & 1.09 & 0.20 & 0.89 & 86.7 & 8.74 & 15.02 & 3.89 \\
\hline
\end{tabular}


Table.3 Yield of maize (Fodder) as influenced by soil application of cattle urine and nitrogen levels in Inceptisol

\begin{tabular}{|c|c|c|}
\hline \multirow[t]{2}{*}{ Treatments } & \multicolumn{2}{|c|}{ Fodder yield $\left(\mathrm{g} \mathrm{pot}^{-1}\right)$} \\
\hline & Green fodder & Dry matter \\
\hline Absolute control & 156.77 & 67.40 \\
\hline RDF & 351.22 & 151.02 \\
\hline GRDF + FYM @ $5 \mathbf{t ~ h a}^{-1}$ & 435.46 & 187.24 \\
\hline $25 \%$ RDN + $75 \%$ N CU + FYM @ $5 \mathrm{t} \mathrm{ha}^{-1}$ & 599.75 & 257.88 \\
\hline $50 \%$ RDN + 50\% N CU + FYM @ $5 \mathrm{tha}^{-1}$ & 833.62 & 358.43 \\
\hline $75 \%$ RDN+ 25\% N CU + FYM @ $5 \mathrm{tha}^{-1}$ & 984 & 423.11 \\
\hline 100\% N CU+FYM @ $5 \mathrm{t} \mathrm{ha}^{-1}$ & 924.81 & 397.67 \\
\hline S.E. \pm & 28.46 & 12.36 \\
\hline CD at $5 \%$ & 87.16 & 37.47 \\
\hline
\end{tabular}

Table.4 Green maize fodder quality (crude protein, fiber and total sugar) as influenced by soil application of cattle urine and nitrogen levels in Inceptisol

\begin{tabular}{|c|c|c|c|}
\hline \multirow[t]{2}{*}{ Treatments } & \multicolumn{3}{|c|}{ Per cent } \\
\hline & $\begin{array}{l}\text { Crude } \\
\text { protein }\end{array}$ & $\begin{array}{l}\text { Crude } \\
\text { Fiber }\end{array}$ & $\begin{array}{l}\text { Total } \\
\text { sugar }\end{array}$ \\
\hline Absolute control & 5.83 & 34.12 & 4.80 \\
\hline RDF & 5.40 & 33.12 & 6.33 \\
\hline GRDF + FYM @ $5 \mathrm{t} \mathrm{ha}^{-1}$ & 6.24 & 33.52 & 7.00 \\
\hline $25 \%$ RDN + $75 \% \mathrm{~N} \mathrm{CU}+$ FYM @ $5 \mathrm{tha}^{-1}$ & 6.24 & 32.14 & 11.00 \\
\hline $50 \%$ RDN + 50\% N CU + FYM @ $5 \mathrm{tha}^{-1}$ & 7.9 & 32.75 & 14.46 \\
\hline $75 \%$ RDN+ 25\% N CU + FYM @ $5 \mathrm{t} \mathrm{ha}^{-1}$ & 8.5 & 31.56 & 14.73 \\
\hline 100\% RDN + FYM @ $5 \mathrm{t} \mathrm{ha}^{-1}$ & 7.07 & 30.81 & 17.86 \\
\hline S.E. \pm & 0.40 & 0.11 & 0.69 \\
\hline CD & 1.22 & 0.34 & 2.11 \\
\hline
\end{tabular}

Table.5 Green maize fodder quality (ADF and NDF) as influenced by soil application of cattle urine and nitrogen levels in Inceptisol

\begin{tabular}{|c|c|c|}
\hline \multirow[t]{2}{*}{ Treatments } & \multicolumn{2}{|c|}{ Per cent } \\
\hline & $\begin{array}{l}\text { Acid detergent } \\
\text { fiber (ADF) }\end{array}$ & $\begin{array}{l}\text { Neutral detergent } \\
\text { Fibre (NDF) }\end{array}$ \\
\hline Absolute control & 25.43 & 57.21 \\
\hline RDF & 25.95 & 57.28 \\
\hline GRDF+FYM @ 5 t ha ${ }^{-1}$ & 26.56 & 58.55 \\
\hline $25 \%$ RDN + $75 \%$ N CU + FYM @ $5 \mathrm{t} \mathrm{ha}^{-1}$ & 27.5 & 59.55 \\
\hline $50 \%$ RDN + 50\% N CU + FYM @ $5 \mathrm{tha}^{-1}$ & 27.77 & 59.8 \\
\hline $75 \%$ RDN+ 25\% N CU + FYM @ $5 \mathrm{tha}^{-1}$ & 28.59 & 61.3 \\
\hline 100\% RDN + FYM @ $5 \mathrm{t} \mathrm{ha}^{-1}$ & 28.72 & 61.42 \\
\hline S.E. \pm & 0.12 & 0.28 \\
\hline CD & 0.38 & 0.86 \\
\hline
\end{tabular}


Fig.1 Height of maize (fodder) as influenced by soil application of cattle urine and nitrogen levels in Inceptisol

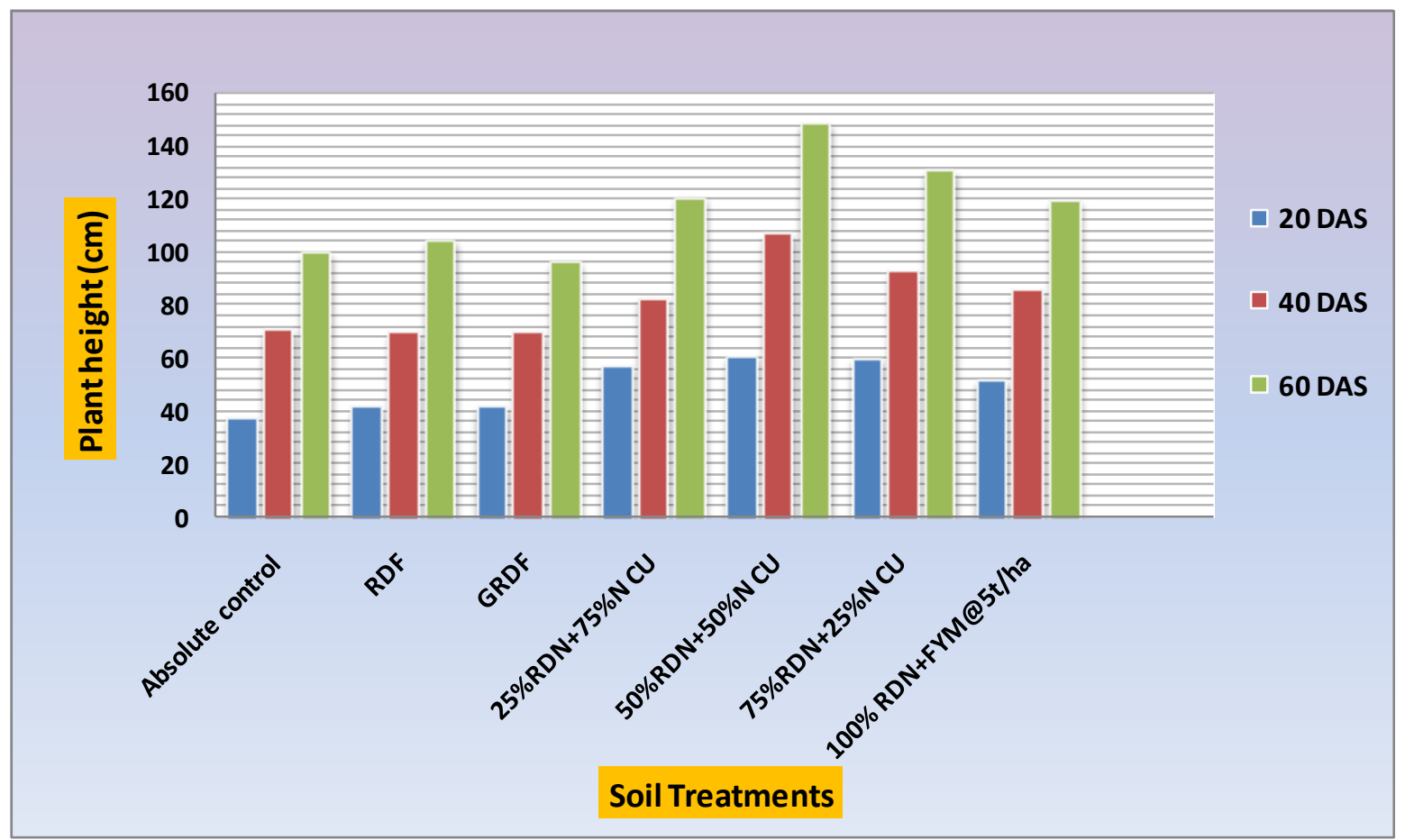

Fig.2 Number of functional leaves of maize (fodder) as influenced by soil application of cattle urine and nitrogen levels in Inceptisol

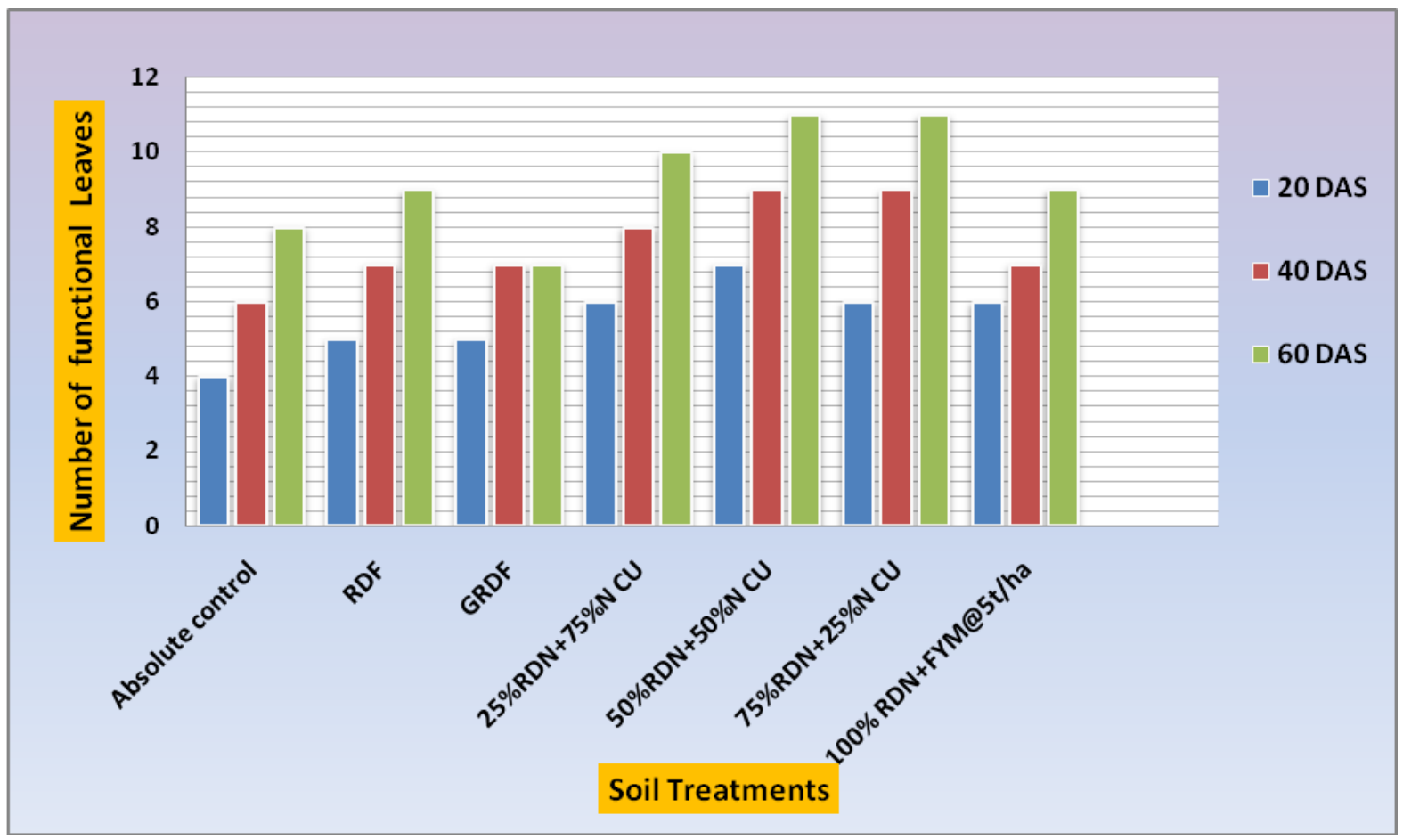


Fig.3 Leaf area of maize (fodder) as influenced by soil application of cattle urine and nitrogen levels in Inceptisol

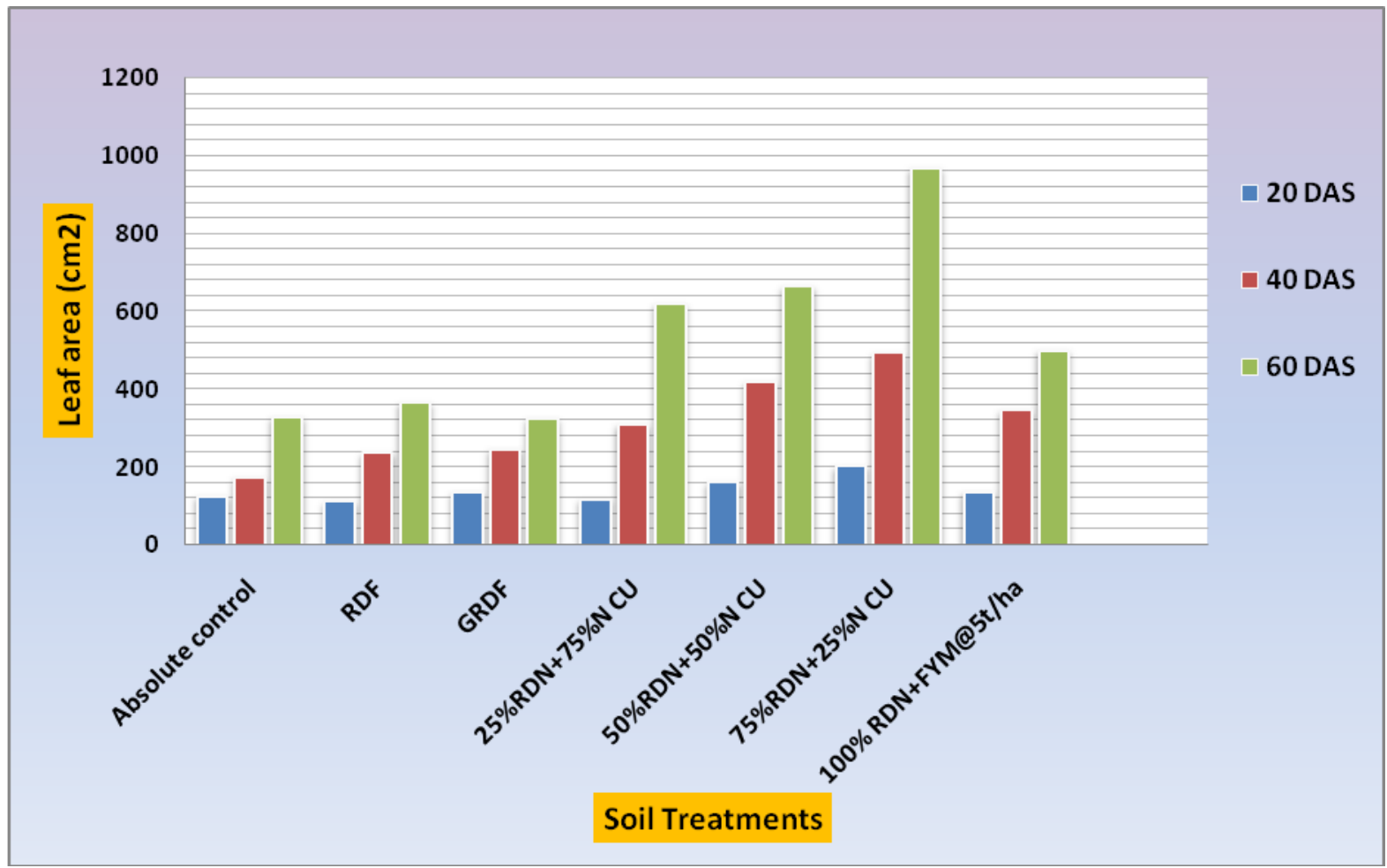

Fig.4 Chlorophyll content in maize (fodder) as influenced by soil application of cattle urine and nitrogen levels in Inceptisol

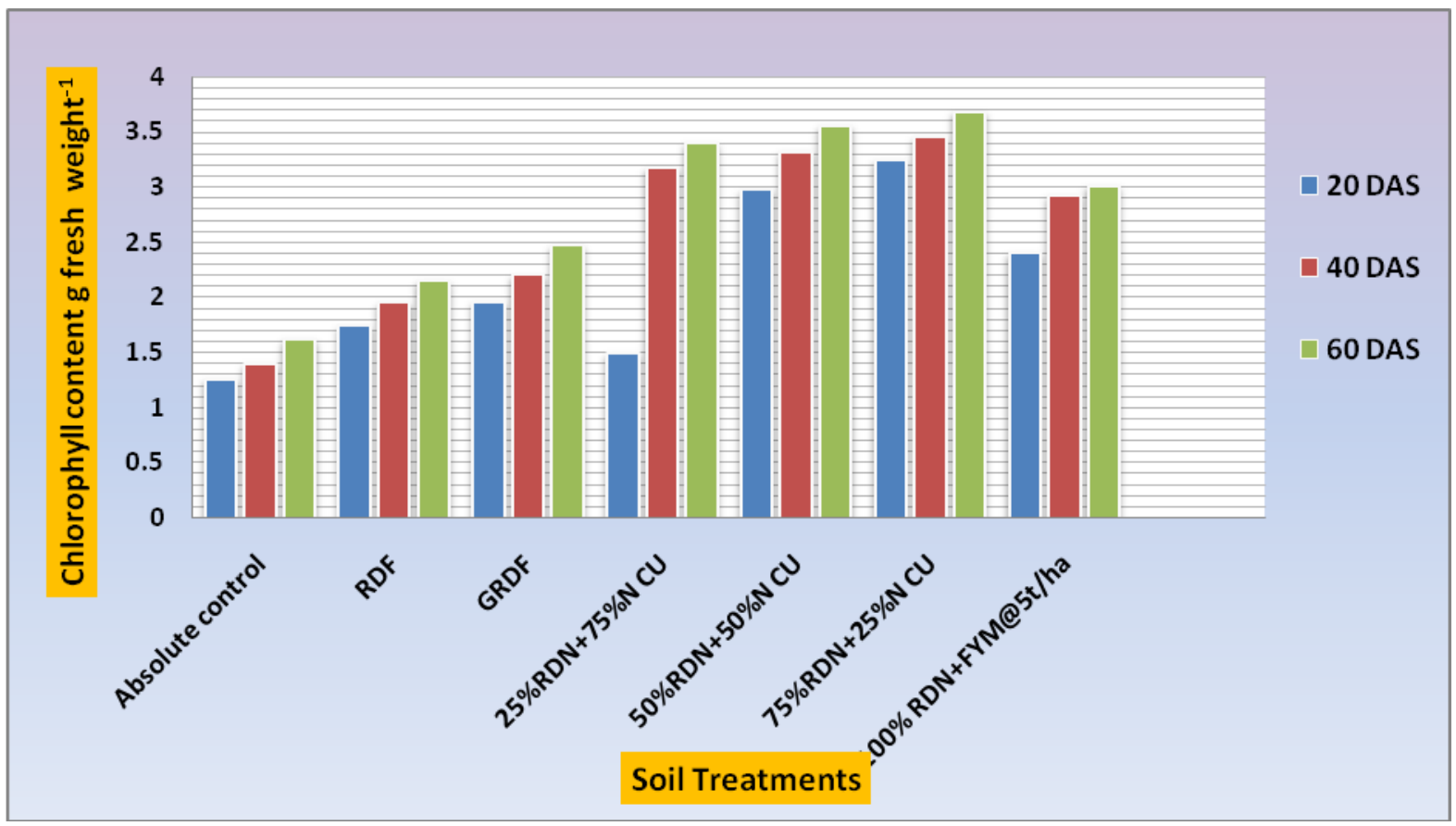




\section{Green fodder and dry matter yield}

Soil application of $75 \%$ RDN through urea + 25\% N through cattle urine with FYM @ $5 \mathrm{t}$ $\mathrm{ha}^{-1}$ recorded significantly higher green fodder $\left(984 \mathrm{~g} \mathrm{pot}^{-1}\right)$ and dry matter (423.11 $\left.\mathrm{g} \mathrm{pot}^{-1}\right)$ yield of maize which was closely followed and statistically at par with the application of 100\% RDN through cattle urine + FYM @ $5 \mathrm{t}$ $\mathrm{ha}^{-1}$ (924.8 and $397.67 \mathrm{~g} \mathrm{pot}^{-1}$ ) respectively (table 3). Further 50\% $\mathrm{N}$ application through cattle urine along with 50\% RDN through urea also recorded moderate green fodder $(833.62 \mathrm{~g}$ pot $^{-1}$ ) and dry matter (358.43 $\left.\mathrm{g} \mathrm{pot}^{-1}\right)$ yield than rest of the treatments. Cattle urine application in soil for the substitution of nitrogen might have improved fertility of soil. As it contains considerable amount of nitrogen, potassium, calcium, magnesium and sulphate with hormones, enzymes and certain growth promoting substances which enhances plant height, number of functional leaves and leaf area leading to more photosynthetic activity thereby resulting in higher green and dry fodder yield. Higher leaf area and nutrient uptake might have contributed for higher yield. Verma (1989) reported that application of nitrogen @ $150 \mathrm{~kg} \mathrm{ha}^{-1}$ through urine recorded higher biological and curd yield of broccoli which was followed by application of nitrogen@50 kg ha ${ }^{-1}$. Higher agronomic yield parameters of maize and improved fertility status of soil by using cattle urine was reported by Nwite (2015). Similar results were also quoted by Nelson et al., (2009), Singh et al., (2014).

\section{Quality of fodder maize}

Quality of fodder maize in respect of crude protein, fiber and total sugar content significantly influenced by the soil application of cattle urine and nitrogen levels. significantly higher crude protein $(8.5 \%)$ was reported with the application of $75 \% \mathrm{RDN}$ through urea $+25 \% \mathrm{~N}$ through cattle
urine+FYM@ $5 \mathrm{tha}^{-1}$ which was found to be statistically at par with 50\% RDN through urea $+50 \%$ RDN through cattle urine + FYM @ $5 \mathrm{t} \mathrm{ha}^{-1}(7.9 \%)$ (table 4 and 5)

The data presented in table 4 indicated that application of cattle urine for the substitution of nitrogen reported decreasing crude fiber content in fodder maize. The crude fiber content was ranged from $30.81 \%$ obtained with application of $100 \% \mathrm{~N}$ through cattle urine+FYM @ $@ \mathrm{t} \mathrm{ha}^{-1}$ to $34.12 \%$ with absolute control. The control treatment significantly produced maximum crude fiber $((34.12 \%)$ as compare to rest of the treatments. Minimum crude fiber was recorded in those pots which received 100\% nitrogen through cattle urine + FYM @ $5 \mathrm{tha}$ ${ }^{1}$. The total sugar content in fodder maize was also influenced significantly due to the application of nitrogen and cattle urine. Significantly higher total sugar $(17.86 \%)$ was recorded in fodder maize supplied with $100 \%$ $\mathrm{N}$ cattle urine along with FYM @ $5 \mathrm{t} \mathrm{ha}^{-1}$. While application of $75 \%$ RDN through urea $+25 \% \mathrm{~N}$ through cattle urine + FYM @ $5 \mathrm{t}$ $\mathrm{ha}^{-1}(14.73 \%)$ and $50 \%$ RDN through urea + $50 \% \mathrm{~N}$ through cattle urine + FYM @ $5 \mathrm{t} \mathrm{ha}^{-1}$ recorded statistically at par results for total sugar content in fodder maize. While lowest total sugar was reported in absolute control $(4.80 \%)$. Application of cattle urine for the substitution of nitrogen were recorded higher total sugar which might be due to the higher microbial activity and enhanced magnitude of nutrients biocycling leads to higher mineralization thereby more absorption of nutrients leads higher sugar content.

The data presented in table 5 showed that soil application of cattle urine for nitrogen substitution had significant effect on ADF and NDF content in green fodder maize. ADF content in green fodder maize was ranged between 25.43 to $28.72 \%$ while that of NDF from 57.21 to $61.42 \%$. Nitrogen application 
either through cattle urine along with inorganic nitrogen fertilizers reported decreasing trend in ADF and NDF content. Significantly lower ADF (25.43\%) and NDF $(57.12 \%)$ was reported with the application of $100 \% \mathrm{~N}$ through cattle urine + FYM @ 5t/ha while application of cattle urine for nitrogen substitution either @ 25, 50 and 75\% recorded decreasing trade ADF as well as NDF content in green fodder maize. The $\mathrm{ADF}$ is used to estimate energetic value of maize silage and because it is constituted from cellulose, lignin and proteins, it is the component that is most related to forage digestibility (Castillo Jimenez et al., 2009).

\section{References}

Aisha, S., N. Sunarlim and B. Solfan (2011) Effect of fermented beef urine with different dosage and interval of giving to plant growth of sawi (Brassica juncea L.) Journal of Agrotechnology, State Islamic university of Sultan SyrifKasim Riau.

A.O.A.C. (1990) Official Methods of Analysis, 12 th Edn., Association of Official. Analytical Chemists, Washington, D.C.

Castilo Jimenez, M; Rojas Bourrillon, A:, WingChing -Jonas, R. (2009) Nutritional value of silage made with a mixture of corn and mung bean (Vigna radiata). Aronimia Costarricense 33,133-146.

Chapman, H. D. and Pratt, P. F. (1961) Methods of Analysis for Soil, Plant and Water.pp.309. Division of Agricultural Science, California University, USA

Chute, K. H., Deotale, R. D., Jadhav, G. N. and Meshram, S. D. (2017) Influence of cow urine and NAA on chemical, biochemical and yield contributing parameters and yield of linseed. Bull. Env.Pharmacol. Life Science 6, 425430.
Gopakkali P. and Sharnappa (2013) Effect of organic production techniques on the growth, yield quality and economics of chili (Capsicum annum) and soil quality in dry zone of Karnataka. Indian Journal of Agronomy 56, 182187.

Goswami, N. N. (2006) Soil testing as unique tool for integrated and balanced fertilizers use for optimizing production-issues, options and limitations. A key note address delivered at National Seminar on Soil testing for Balanced and Integrated use of fertilizers during 17 March, 1-17.

Hedge J. E. and Hofreiter B. T. (1962) In: Carbohydrates chemistry 17, (eds.Whistler, R. L. and Bemiller, J. N.) Academic press, NewYork.

Iqbal, A., Iqbal, M. A., Raza, A., Akbar, N., Abbas, N. and Khan, H. Z. (2014) Integrated Nitrogen Management Studies in Forage Maize. AmericanEurasian Journal Agriculture and Environment Science 14, 744-747.

Jackson, M. L. (1973) Soil Chemical Analysis - Prentice Hall of India Pvt. Ltd., New Delhi, pp.69-182.

Knudsen, D., Peterson, G. A. and Pratt, P. F. (1982) Lithium, sodium potassium. In: Methods of Soil Analysis, part-2. Page, A.L. (Ed.) Madison, Wisconsin, USA, 225-245.

Ledgard, S. F., Sheath, G. W., Gillingham, A. G. (1982) Influence of some soil and pasture components on the growth of hill country pastures L. Winter and spring production. New Zealand Journal of Experimental Agriculture 10, 239-244.

Nelson, D. W. and Sommer, L. E. (1982) Total carbon, organic carbon and organic matter. Laboratory Methods.In Method of soil analysis (A.L. Page et al., Eds) Part-2, $2^{\text {nd }}$ edn.American Society of Agronomy Inc. Soil Science 
Society of America Inc.Madison, Wisconsin, USA, 539-579.

Nwite J. N. (2015) Effect of different urine sources on soil chemical properties and maize yield in Abakaliki, southeastern Nigeria. International Journal of Advance Agricultural Research 3, 3136.

Olsen, S. R., Col C. V., Watanabe, F. S. and Dean, L. A. (1954) Estimation of available phosphorous in soils by estimation with $\mathrm{NaHCO}_{3}$. USDA Cir. 939 C.A. Part II Chemical and microbiological properties. American Society Of Agronomy Inc., Madison, Wisconsin, USA.

Singh, M. K., Singh R, P. and Rai, S. (2014) Effect of Nitrogen levels and cow urine on soil $\mathrm{N}$ status, growth and yield of paddy (Oryza Sativa L.). Environment and Ecology 32, 12771281.

Subbiah, B. V. and Asijia, G. L. (1956) A rapid procedure for the estimation of available nitrogen in soils. Current Science 25, 259-260.

Pradhan Swayamprabha, S., Verma, S., Kumari, S. and Yashwant Singh. (2018) Bio-efficacy of cow urine on crop production: A review. International Journal of Chemical Studies6, 298-301.

Tanko, U., Musa, and Hassan, U. T. (2011) Leaf area determination for maize (Zea mays L.). Journal of Biology, Agriculture and Healthcare, 4, 130111.

Tamaraker S. K. (2016) Effect of plant growth regulator, vermicompost and cow urine on vegetative growth, flowering, corm production and vase life of gladiolus var. Candyman, Ph.D. thesis submitted to the Indira Gandhi Krishi Vishwavidyalaya, Raipur, Chattisgarh.

Verma, S. S. (1989) Effect of nitrogen and seed rate and method of sowing on forage oat. Forage Res. 15, 29.

\section{How to cite this article:}

Janjal, P. S., A. B. Jadhav, A. V. Patil and Pachpute, S. T. 2021. Growth, Yield, Nutrient Uptake and Quality of Maize (Fodder) as Influenced by Soil Application of Cattle Urine and Nitrogen Levels in Inceptisol. Int.J.Curr.Microbiol.App.Sci. 10(07): 710-721.

doi: https://doi.org/10.20546/ijcmas.2021.1007.077 